\title{
Persepsi dan Tingkat Keselamatan Pengguna Sepeda di Kota Palu
}

\author{
N.A. Ridwan ${ }^{\mathrm{a} *}$, R. Ramlan ${ }^{\mathrm{a}}$, S.P. Lestari ${ }^{\mathrm{a}}$ dan I. Fadilah ${ }^{\mathrm{a}}$ \\ a Jurusan Teknik Sipil, Fakultas Teknik Universitas Tadulako, Jalan Soekarno Hatta Km. 9, Palu, Sulawesi Tengah, Indonesia, 94112 \\ ${ }^{*}$ Corresponding author's e-mail: nurulanisarp@gmail.com
}

Received: 04 January 2022; revised: 27 January 2022; accepted: 2 February 2022

\begin{abstract}
Since the outbreak of the Covid-19 Pandemic in Indonesia, there has been an increase in public interest in using bicycles, especially when exercising. This study aims to determine the characteristics, behavior, safety, habits, and perceptions of bicycle us ers in Palu City at this time, then a questionnaire was distributed with a total of 132 participating respondents. The method of descriptive and Frekuensi data analysis shows that the characteristics of cyclists generally cycle in weekend $(88,6 \%)$ which is to exercise or visit sightseeing spots $(78 \%)$, cyclist behavior is generally still good in the relationship between road users $(98,5 \%)$, cyclist safety is indicated by the accident rate of $43,2 \%$ which is generally a single traffic accident $(91,2 \%)$, cyclist generally increases their habit of exercising or visiting the sightseeing spots $(10,6 \%)$ and visiting friends or family's houses $(5,3 \%)$ and the perception of cyclist who generally understands safety requirements when cycling $(79,5 \%)$ and agrees that cycling can improve environmental quality $(90,2 \%)$.
\end{abstract}

Keywords: characteristics, behavior, safety, habits, perception.

\begin{abstract}
Abstrak: Sejak mewabahnya pandemi covid-19 di Indonesia, terdapat peningkatan minat masyarakat dalam menggunakan sepeda khususnya saat berolahraga. Penelitian ini bertujuan untuk mengetahui karakteristik, perilaku, keselamatan, kebiasaan dan persepsi pengguna sepeda di Kota Palu saat ini, maka disebarkanlah kuesioner dengan total responden yang berpartisipasi sebanyak 132 orang. Metode analisis data secara deskriptif dan frekuensi menunjukkan hasil penelitian bahwa karakteristik pesepeda umumnya bersepeda saat weekend (sabtu-minggu) $(88,6 \%)$ untuk berolahraga atau berkunjung ke tempat wisata (78\%), perilaku pesepeda umumnya masih baik dalam hubungan antar pengguna jalan $(98,5 \%)$, keselamatan pesepeda ditunjukkan dengan tingkat kecelakaan sebesar $43,2 \%$ yang umumnya kecelakaan lalu lintas tunggal $(91,2 \%)$, kebiasaan pesepeda yang umumnya meningkat untuk berolahraga atau berkunjung ke tempat wisata $(10,6 \%)$ dan berkunjung ke rumah teman atau keluarga $(5,3 \%)$ dan persepsi pesepeda yang umumnya memahami persyaratan keselamatan saat bersepeda (79,5\%) dan setuju bahwa bersepeda dapat meningkatkan kualitas lingkungan $(90,2 \%)$.
\end{abstract}

Kata kunci: karakteristik, perilaku, keselamatan, kebiasaan, persepsi.

\section{Pendahuluan}

Pandemi Covid-19 yang mewabah di seluruh dunia sejak akhir tahun 2019 lalu menyebabkan adanya pembatasan kehidupan sosial di lingkungan masyarakat. Pembatasan kehidupan sosial atau biasa disebut dengan social distancing bertujuan untuk memutuskan rantai penyebaran virus corona dengan membatasi kunjungan ke tempat ramai dan kontak langsung dengan orang lain. Hal ini menyebabkan terjadinya perubahan perilaku pola hidup masyarakat secara menyeluruh. Salah satu contohnya yaitu meningkatnya minat masyarakat yang memiliki cukup waktu luang untuk berolahraga dengan menggunakan sepeda.

Kegiatan bersepeda memiliki banyak manfaat baik yaitu dari segi kesehatan, lingkungan, menghemat BBM (Bahan Bakar Minyak), penyaluran hobi serta menambah wawasan dan persahabatan dalam komunitas sepeda [1]. Selain itu, sepeda juga merupakan salah satu alternatif sarana transportasi yang lebih ramah lingkungan untuk mewujudkan kota yang berwawasan lingkungan yang menjadi konsep penyeimbang aktivitas pembangunan yang kian pesat. Di beberapa kota di Indonesia mulai menambahkan jalur sepeda di ruas jalan tertentu. Adanya jalur yang dikhususkan untuk lalu lintas pengguna sepeda dipisah dari lalu lintas kendaraan bermotor untuk meningkatkan keselamatan lalu lintas pengguna sepeda.
Seorang pengamat transportasi Universitas Katolik (Unika) Soegijapranata Semarang, Joko Setijowarno mengatakan bahwa Pemerintah Daerah perlu membangun infrastruktur jalur khusus sepeda untuk kenyamanan dan keselamatan pengguna sepeda yang sedang tren di masa pandemik Covid-19. Membangun jalur sepeda akan mendukung program kota sehat dengan Kabupaten Kota Sehat (KKS) yang sudah dimulai tahun 2005. Sebab bersepeda menyehatkan badan [2]. Adapun di Kota Palu belum terdapat infrastruktur jalur sepeda. Dengan membangun infrastuktur jalur sepeda diharapkan dapat mewujudkan jalur sepeda berkeselamatan. Sebelum mendesain jalur sepeda, sebaiknya dilakukan penggalian informasi mengenai karakteristik pengguna sepeda [3-7]. Informasi tersebut diharapkan dapat digunakan sebagai konsep dasar dalam perencanaan jalur sepeda yang sesuai dengan kebutuhan dan keinginan pengguna sepeda.

\section{Metode Penelitian}

\subsection{Data}

Jenis data yang digunakan dalam penelitian ini, yaitu data primer. Data primer adalah data yang diperoleh secara langsung dari lokasi penelitian, data ini berupa kuesioner terhadap pengguna sepeda dan komunitas sepeda di Kota Palu. 


\subsection{Metode dan Tahapan Penelitian}

Penelitian ini dilakukan dengan menyebarkan kuesioner pada para pengguna sepeda dan komunitas sepeda secara online (google form) dengan link/ tautan (https://forms.gle/AmArUvB7z24bytXQ7) kuesioner juga dibagikan melalui media social dan media komunikasi digital (Daring). Kemudian data yang telah dikumpulkan akan dilakukan analisisnya menggunakan Microsoft Excel dan aplikasi SPSS (Statistical Package fot the Social Sciences) [8-12].

\section{Hasil dan Pembahasan}

\subsection{Proses Pengumpulan Data}

Penelitian ini mengambil responden yang merupakan pengguna sepeda baik pria maupun Wanita yang berumur $\geq 15$ tahun. Pembagian kuesioner penelitian dilakukan secara online selama satu bulan penuh mulai dari tanggal 30 agustus 2021 - 30 september 2021 dengan membagikan link (https://forms.gle/AmArUvB7z24bytXQ7) kepada para pengguna sepeda dan komunitas sepeda di Kota Palu. jumlah responden yang berpartisipasi dalam penelitian ini berjumlah 132 orang.

\subsection{Uji Validitas dan Uji Reabilitas}

Adapun pengujian validitas dan reabilitas ini dilakukan terhadap pertanyaan yang bersifat skala likert dalam kuesioner penelitian. Hasil uji validitas dan reabilitas tersebut ditunjukkan pada Tabel 1 dan Tabel 2.

Tabel 1. Uji validitas

\begin{tabular}{cccc}
\hline Pertanyaan & R hitung & R tabel & Keterangan \\
\hline Kebiasaan Bersepeda Saat Ini (D) & & \\
\hline D1 & 0.728 & 0.1710 & Valid \\
\hline D2 & 0.646 & 0.1710 & Valid \\
\hline D3 & 0.610 & 0.1710 & Valid \\
\hline D4 & 0.743 & 0.1710 & Valid \\
\hline D5 & 0.757 & 0.1710 & Valid \\
\hline Kebiasaan Bersepeda Sebelum Pandemi $(\mathrm{E})$ & \\
\hline E1 & 0.765 & 0.1710 & Valid \\
\hline E2 & 0.754 & 0.1710 & Valid \\
\hline E3 & 0.827 & 0.1710 & Valid \\
\hline E4 & 0.803 & 0.1710 & Valid \\
\hline E5 & 0.771 & 0.1710 & Valid \\
\hline Persepsi Pesepeda $($ F $)$ & & \\
\hline F1 & 0.508 & 0.1710 & Valid \\
\hline F2 & 0.545 & 0.1710 & Valid \\
\hline F3 & 0.374 & 0.1710 & Valid \\
\hline F4 & 0.515 & 0.1710 & Valid \\
\hline F5 & 0.628 & 0.1710 & Valid \\
\hline F6 & 0.531 & 0.1710 & Valid \\
\hline F7 & 0.719 & 0.1710 & Valid \\
\hline F8 & 0.755 & 0.1710 & Valid \\
\hline F9 & 0.695 & 0.1710 & Valid \\
\hline F10 & 0.681 & 0.1710 & Valid \\
\hline F11 & 0.1710 & Valid \\
\hline F12 & 0.600 & 0.1710 & Valid \\
\hline F13 & 0.550 & 0.1710 & Valid \\
\hline F14 & 0.1710 & Valid \\
\hline F15 & 0.1710 & Valid \\
\hline F16 & 0.1710 & Valid \\
\hline
\end{tabular}

Pengujian validitas ini menggunakan alat ukur bivariates pearson. Jika $r$ hitung $>r$ tabel, maka indikator dalam penelitian ini dikatakan valid. Berdasarkan tabel diatas, semua $r$ hitung $>0.1710$, sehingga dapat disimpulkan bahwa angket pada pertanyaan D, E dan F ini valid.

Tabel 2. Uji reabilitas

\begin{tabular}{ccc}
\hline Variabel & Cronbach's Alpha & Keterangan \\
\hline D & 0.727 & Reliabel \\
\hline E & 0.839 & Reliabel \\
\hline F & 0.855 & Reliabel \\
\hline
\end{tabular}

Variabel yang terlibat dalam suatu penelitian dikatakan andal atau reabilitas mencukupi jika memberikan nilai cronbach alpha $>0.70$ [13-15]. Berdasarkan hasil uji reabilitas pada tabel, angket pada pertanyaan bagian D, E, F ini mempunyai nilai cronbach alpha $>0.70$, sehingga dapat disimpulkan bahwa alat ukut tersebut andal.

\subsection{Gambaran Umum Responden}

Adapun gambaran umum responden yang berpartisipasi dalam penelitian ini ditunjukkan pada Tabel 3, Tabel 4 dan Tabel 5.

Tabel 3. Jenis kelamin

\begin{tabular}{lcc}
\hline & Frekuensi & Persen \\
\hline Laki-laki & 74 & 56.1 \\
\hline Perempuan & 58 & 43.9 \\
\hline Total & 132 & 100 \\
\hline
\end{tabular}

Berdasarkan Tabel 3 dapat diketahui bahwa kelompok jenis kelamin laki-laki lebih banyak dibandingkan dengan kelompok jenis kelamin perempuan. adapun hal ini terjadi karena faktor kebetulan pada saat penyebaran kuesioner dimana responden laki-laki lebih banyak berpartisipasi dalam pengisian kuesioner ini.

Tabel 4. Usia responden

\begin{tabular}{lcc}
\hline Usia & Frekuensi & Persen \\
\hline 15-20 Tahun & 26 & 19.70 \\
\hline 21-25 Tahun & 86 & 65.15 \\
\hline 26-30 Tahun & 7 & 5.30 \\
\hline 31-35 Tahun & 2 & 1.52 \\
\hline 36-40 Tahun & 7 & 5.30 \\
\hline 41-45 Tahun & 1 & 0.76 \\
\hline 46-50 Tahun & 2 & 1.52 \\
\hline 51-55 Tahun & 1 & 0.76 \\
\hline Total & 132 & 100 \\
\hline
\end{tabular}

Berdasarkan Tabel 4 atas dapat diketahui bahwa kelompok usia yang paling banyak berpartisipasi dalam penelitian ini adalah kelompok usia 21-25 tahun. Berdasarkan Tabel 5 dapat diketahui bahwa kelompok responden yang merupakan anggota komunitas sepeda paling sedikit berpartisipasi dalam penelitian ini 
REKONSTRUKSI TADULAKO: Civil Engineering Journal on Research and Development, Vol. 3(1), March 2022

dibandingkan dengan responden yang bukan anggota komunitas sepeda.

Tabel 5. Keanggotaan komunitas sepeda

\begin{tabular}{lcc}
\hline Keanggotaan & Frekuensi & Persen \\
\hline $\begin{array}{l}\text { Anggota Komunitas } \\
\text { Sepeda }\end{array}$ & 17 & 12.9 \\
\hline $\begin{array}{l}\text { Bukan Anggota } \\
\text { Komunitas Sepeda }\end{array}$ & 115 & 87.1 \\
\hline Total & 132 & 100 \\
\hline
\end{tabular}

\subsection{Karakteristik Responden}

Adapun karakteristik responden yang berpartisipasi dalam penelitian ini didapatkan dari hasil pengisian kuesioner pada Bagian I Pola Perjalanan yang ditunjukkan pada tabel-tabel berikut.

Tabel 6. Terakhir kali bersepeda

\begin{tabular}{lcc}
\hline Usia & Frekuensi & Persen \\
\hline minggu ini & 23 & 17.4 \\
\hline minggu lalu & 11 & 8.3 \\
\hline bulan lalu & 10 & 7.6 \\
\hline lebih dari satu bulan lalu & 31 & 23.5 \\
\hline $\begin{array}{l}\text { sudah lama tidak } \\
\text { menggunakan sepeda }\end{array}$ & 57 & 43.2 \\
\hline Total & 132 & 100 \\
\hline
\end{tabular}

Berdasarkan Tabel 6 dapat diketahui bahwa umumnya responden yang berpartisipasi sudah lama tidak menggunakan sepeda.

Tabel 7. Saat paling sering bersepeda

\begin{tabular}{|c|c|c|}
\hline Waktu & Frekuensi & Persen \\
\hline Setiap hari & 13 & 9.8 \\
\hline Weekdays (Senin-Jumat) & 2 & 1.5 \\
\hline $\begin{array}{l}\text { Weekend (Sabtu- } \\
\text { Minggu) }\end{array}$ & 117 & 88.6 \\
\hline Total & 132 & 100 \\
\hline Waktu & Frekuensi & Persen \\
\hline Pagi & 60 & 45.5 \\
\hline Siang & 1 & 0.8 \\
\hline Sore & 68 & 51.5 \\
\hline Malam & 3 & 2.3 \\
\hline Total & 132 & 100 \\
\hline
\end{tabular}

Berdasarkan Tabel 7 dapat diketahui bahwa pesepeda umumnya bersepeda pada saat weekend (sabtu-minggu) dan saat sore hari.

Tabel 8. Total waktu perjalanan

\begin{tabular}{lcc}
\hline Waktu & Frekuensi & Persen \\
\hline$<15$ Menit & 20 & 15.2 \\
\hline $15-30$ Menit & 42 & 31.8 \\
\hline$>30$ Menit & 23 & 17.4 \\
\hline$>1$ Jam & 47 & 35.6 \\
\hline Total & 132 & 100 \\
\hline
\end{tabular}

Berdasarkan Tabel 8 dapat diketahui bahwa umumnya pesepeda melakukan perjalanan dengan total waktu $>1$ jam.

Tabel 9. Jarak total bersepeda

\begin{tabular}{lcc}
\hline \multicolumn{1}{c}{ Jarak } & Frekuensi & Persen \\
\hline$<1$ Kilometer & 34 & 25.8 \\
\hline$>$ 1 Kilometer & 58 & 43.9 \\
\hline$>5$ Kilometer & 40 & 30.3 \\
\hline Total & 132 & 100 \\
\hline
\end{tabular}

Berdasarkan Tabel 9 dapat diketahui bahwa umumnya pesepeda bersepeda dengan jarak total $>1$ kilometer.

Tabel 10. Tujuan bersepeda

\begin{tabular}{lcc}
\hline \multicolumn{1}{c}{ Tujuan } & Frekuensi & Persen \\
\hline $\begin{array}{l}\text { Berolahraga atau } \\
\text { berkunjung ke tempat } \\
\text { wisata }\end{array}$ & 103 & 78.0 \\
\hline $\begin{array}{l}\text { Mengunjungi kantor atau } \\
\text { sekolah }\end{array}$ & 4 & 3.0 \\
\hline $\begin{array}{l}\text { Berbelanja (Ke pasar, } \\
\text { minimarket, dll) }\end{array}$ & 2 & 1.5 \\
\hline $\begin{array}{l}\text { Kegiatan Sosial (Ke rumah } \\
\text { teman, saudara, dll) }\end{array}$ & 14 & 10.6 \\
\hline Cari Angin & 1 & 0.8 \\
\hline Mengisi waktu luang & 1 & 0.8 \\
\hline Keliling BTN/Kompleks & 1 & 1.5 \\
\hline Bermain & 2 & 0.8 \\
\hline $\begin{array}{l}\text { Hanya untuk bersenang- } \\
\text { senang }\end{array}$ & 1 & 0.8 \\
\hline Diet & 1 & 0.8 \\
\hline $\begin{array}{l}\text { Bersepeda dapat } \\
\text { mengoptimalkan kinerja } \\
\text { sistem kardiovaskular }\end{array}$ & 132 & 100 \\
\hline Total & & \\
\hline
\end{tabular}

Berdasarkan Tabel 10 dapat diketahui bahwa tujuan bersepeda oleh para pesepeda umumnya untuk berolahraga atau berkunjung ke tempat wisata.

Tabel 11. Kegiatan bersepeda

\begin{tabular}{|c|c|c|}
\hline Kegiatan Bersepeda & Frekuensi & Persen \\
\hline Sendirian & 61 & 46.2 \\
\hline $\begin{array}{l}\text { Bersama } 1-5 \text { orang } \\
\text { teman/saudara/anggota kel. }\end{array}$ & 52 & 39.4 \\
\hline $\begin{array}{l}\text { Bersama lebih dari } 5 \text { orang } \\
\text { teman/saudara/anggota } \\
\text { keluarga saya }\end{array}$ & 19 & 14.4 \\
\hline Total & 132 & 100 \\
\hline Kegiatan Bersepeda & Frekuensi & Persen \\
\hline Bersepeda secara berbaris & 108 & 81.8 \\
\hline Bersepeda secara bersejajar & 24 & 18.2 \\
\hline Total & 132 & 100 \\
\hline Kegiatan Bersepeda & Frekuensi & Persen \\
\hline Cerah & 92 & 69.7 \\
\hline Berawan & 40 & 30.3 \\
\hline Total & 132 & 100 \\
\hline
\end{tabular}


Berdasarkan Tabel 11 dapat diketahui bahwa pesepeda umumnya bersepeda sendirian, kemudian apabila bersepeda bersama teman/ keluarga pesepeda akan bersepeda secara berbaris. Adapun cuaca saat terakhir kali pesepeda bersepeda adalah cerah.

\subsection{Perilaku Bersepeda}

Adapun perilaku bersepeda oleh para pengguna sepeda di Kota Palu yang di wakilkan oleh responden yang berpartisipasi didapatkan dari hasil pengisian kuesioner pada Bagian II Pegetahuan Tentang Keselamatan Berlalu Lintas yang ditunjukkan oleh Tabel 12 - Tabel 13.

Tabel 12. Penggunaan lampu dan atribut bersepeda

(*) Apakah Anda menyalakan lampu dan menggunakan pakaian dan/atau atribut yang dapat memantulkan cahaya saat bersepeda di malam hari/kondisi tertentu?

\begin{tabular}{lcc}
\hline & Frekuensi & Persen \\
\hline Ya, Saya melakukan keduanya & 26 & 19.7 \\
\hline Saya hanya menyalakan lampu & 25 & 18.9 \\
\hline $\begin{array}{l}\text { Saya hanya menggunakan } \\
\text { pakaian/ atribut yang dapat } \\
\text { memantulkan cahaya }\end{array}$ & 10 & 7.6 \\
\hline Saya tidak melakukan keduanya & 71 & 53.8 \\
\hline Total & 132 & 100 \\
\hline
\end{tabular}

(*) Apakah anda menggunakan alat pelindung diri berupa helm?

\begin{tabular}{lcc}
\hline & Frekuensi & Persen \\
\hline Ya & 44 & 33.3 \\
\hline Tidak & 88 & 66.7 \\
\hline Total & 132 & 100 \\
\hline
\end{tabular}

Berdasarkan Tabel 12 dapat diketahui bahwa umumnya pesepeda di Kota Palu tidak menggunakan helm saat bersepeda maupun lampu dan atribut yang dapat memantulkan cahaya saat bersepeda malam hari/ kondisi tertentu.

Tabel 13. Interaksi pesepeda dengan pengguna jalan

(*) Apakah Anda menggunakan sepeda secara tertib dan memperhatikan keselamatan pengguna jalan lain?

\begin{tabular}{lcc}
\hline & Frekuensi & Persen \\
\hline Ya & 130 & 98.5 \\
\hline Tidak & 2 & 1.5 \\
\hline Total & 132 & 100 \\
\hline
\end{tabular}

(*) Apakah Anda menjaga jarak aman dari pengguna jalan lain dan membawa sepeda dengan penuh konsentrasi?

\begin{tabular}{lcc}
\hline & Frekuensi & Persen \\
\hline Ya & 130 & 98.5 \\
\hline Tidak & 2 & 1.5 \\
\hline Total & 132 & 100 \\
\hline
\end{tabular}

Lanjutan Tabel 13. Interaksi pesepeda dengan pengguna jalan

(*) Ketika akan berbelok, berhenti, atau berbalik arah apakah Anda memperhatikan situasi lalu lintas di depan, di samping, dan di belakang sepeda serta memberikan tanda berupa isyarat tangan?

\begin{tabular}{lcc}
\hline & Frekuensi & Persen \\
\hline Ya & 130 & 98.5 \\
\hline Tidak & 2 & 1.5 \\
\hline Total & 132 & 100 \\
\hline
\end{tabular}

(*) Apakah Anda berkendara dengan berjajar lebih dari 2 (dua) sepeda?

\begin{tabular}{lcc}
\hline & Frekuensi & Persen \\
\hline Ya & 32 & 24.2 \\
\hline Tidak & 100 & 75.8 \\
\hline Total & 132 & 100 \\
\hline \multicolumn{3}{c}{ Frekuensi } \\
\hline $\begin{array}{l}* \\
\text { perangkat } \text { Apakah Anda menggunakan atau mengoperasikan } \\
\text { menggunakan piranti dengar? }\end{array}$ \\
\hline \multicolumn{3}{c}{ sarsen } \\
\hline Ya & 21 & Perkendara tanpa \\
\hline Tidak & 111 & 84.1 \\
\hline Total & 132 & 100 \\
\hline
\end{tabular}

Berdasarkan Tabel 13 dapat diketahui bahwa pesepeda di Kota Palu bersepeda secara tertib, memperhatikan keselamatan dan menjaga jarak aman dari pengguna jalan lain, membawa sepeda dengan penuh konsentrasi, memperhatikan situasi lalu lintas serta menggunakan isyarat tangan, tidak bersepeda dengan berjajar lebih dari 2 sepeda dan tidak menggunakan perangkat elektronik seluler tanpa piranti dengar.

\subsection{Keselamatan Bersepeda}

Adapun pengelompokkan ini didapatkan dari hasil pengisian kuesioner pada Bagian II Pegetahuan Tentang Keselamatan Berlalu Lintas yang ditunjukkan oleh Tabel 14 dan Tabel 15.

Tabel 14. Pengetahuan PERMEN No.59 Tahun 2009

(*) Apakah Anda mengetahui Peraturan Menteri No.59 Tahun 2009 yang mengatur tentang petunjuk dan larangan saat bersepeda?

\begin{tabular}{lcc}
\hline & Frekuensi & Persen \\
\hline Ya & 30 & 22.7 \\
\hline Tidak & 102 & 77.3 \\
\hline Total & 132 & 100 \\
\hline
\end{tabular}

Berdasarkan Tabel 14 dapat diketahui bahwa umumnya pesepeda di Kota Palu tidak mengetahui Peraturan Pemerintah No.59 Tahun 2009 yang mengatur tentang keselamatan pesepeda di jalan. 
REKONSTRUKSI TADULAKO: Civil Engineering Journal on Research and Development, Vol. 3(1), March 2022

Tabel 15. Kecelakaan saat bersepeda

\begin{tabular}{|c|c|c|}
\hline Kecelakaan & Frekuensi & Persen \\
\hline $\mathrm{Ya}$ & 57 & 43.2 \\
\hline Tidak & 75 & 56.8 \\
\hline Total & 132 & 100 \\
\hline Kecelakaan & Frekuensi & Persen \\
\hline $\begin{array}{l}\text { Kecelakaan Lalu Lintas } \\
\text { Tunggal }\end{array}$ & 52 & 91.2 \\
\hline $\begin{array}{l}\text { Kecelakaan Lalu Lintas } \\
\text { Ganda }\end{array}$ & 4 & 7.0 \\
\hline Keduanya & 1 & 1.8 \\
\hline Total & 57 & 100 \\
\hline
\end{tabular}

Berdasarkan Tabel 15 dapat diketahui bahwa pesepeda yang pernah mengalami kecelakaan saat bersepeda sebesar $43,2 \%$ dimana diketahui sebesar $91,2 \%$ pesepeda mengalami kecelakaan lalu lintas tunggal.

Tabel 16. Faktor-faktor kecelakaan saat bersepeda

(*) Apakah Anda pernah mengalami kecelakaan lalu lintas karena tidak sarapan/lapar saat bersepeda?

\begin{tabular}{lcc}
\hline & Frekuensi & Persen \\
\hline Pernah & 5 & 3.8 \\
\hline Tidak pernah & 127 & 96.2 \\
\hline Total & 132 & 100 \\
\hline
\end{tabular}

(*) Apakah Anda pernah mengalami kecelakaan lalu lintas karena kesalahan dari pengemudi lain saat berkendara?

\begin{tabular}{lcc}
\hline & Frekuensi & Persen \\
\hline Pernah & 28 & 21.2 \\
\hline Tidak pernah & 104 & 78.8 \\
\hline Total & 132 & 100 \\
\hline
\end{tabular}

(*) Apakah menurut Anda dengan tidak adanya jalur khusus pengguna sepeda/ kendaraan tidak bermotor menjadi salah satu faktor penyebab kecelakaan lalu lintas bagi para pengguna sepeda?

\begin{tabular}{lcc}
\hline & Frekuensi & Persen \\
\hline Ya & 118 & 89.4 \\
\hline Tidak & 14 & 10.6 \\
\hline Total & 132 & 100 \\
\hline
\end{tabular}

(*) Apakah menurut Anda usia pengemudi menjadi salah satu faktor penyebab kecelakaan lalu lintas bagi pengguna sepeda? (misal: emosi belum stabil/ rendahnya refleks)

\begin{tabular}{lcc}
\hline & Frekuensi & Persen \\
\hline Ya & 106 & 80.3 \\
\hline Tidak & 26 & 19.7 \\
\hline Total & 132 & 100 \\
\hline
\end{tabular}
Lanjutan Tabel 16. Faktor-faktor kecelakaan saat
bersepeda

(*) Apakah Anda pernah mengalami kecelakaan lalu lintas karena perkerasan jalan yang berlubang/ bergelombang saat bersepeda?

\begin{tabular}{lcc}
\hline & Frekuensi & Persen \\
\hline Pernah & 48 & 36.4 \\
\hline Tidak pernah & 84 & 63.6 \\
\hline Total & 132 & 100 \\
\hline
\end{tabular}

(*) Apakah Anda pernah mengalami kecelakaan lalu lintas karena cuaca yang tidak mendukung saat bersepeda? (misal: hujan lebat/ cuaca terlalu panas)

\begin{tabular}{lcc}
\hline & Frekuensi & Persen \\
\hline Pernah & 24 & 18.2 \\
\hline Tidak pernah & 108 & 81.8 \\
\hline Total & 132 & 100 \\
\hline
\end{tabular}

(*) Apakah Anda pernah mengalami kecelakaan lalu lintas karena kelengkapan sepeda yang tidak lengkap/ tidak dalam kondisi baik?

\begin{tabular}{lcc}
\hline & Frekuensi & Persen \\
\hline Pernah & 31 & 23.5 \\
\hline Tidak pernah & 101 & 76.5 \\
\hline Total & 132 & 100 \\
\hline
\end{tabular}

(*) Apakah Anda pernah mengalami kecelakaan lalu lintas karena kondisi fisik yang tidak baik saat bersepeda? (misal: sakit kepala/ demam)

\begin{tabular}{lcc}
\hline & Frekuensi & Persen \\
\hline Pernah & 6 & 4.5 \\
\hline Tidak pernah & 126 & 95.5 \\
\hline Total & 132 & 100 \\
\hline
\end{tabular}

(*) Apakah anda pernah mengalami kecelakaan lalu lintas karena tidak disiplin dan tidak memahami peraturan lalu lintas?

\begin{tabular}{lcc}
\hline & Frekuensi & Persen \\
\hline Pernah & 13 & 9.8 \\
\hline Tidak pernah & 119 & 90.2 \\
\hline Total & 132 & 100 \\
\hline
\end{tabular}

Berdasarkan Tabel 16 dapat diketahui bahwa kecelakaan lalu lintas pesepeda di Kota Palu akibat lapar, kesalahan pengemudi lain, perkerasan jalan yang berlubang/ bergelombang, cuaca tidak mendukung, kelengkapan sepeda yang tidak lengkap/ tidak dalam kondisi baik, kondisi fisik yang tidak baik serta tidak disiplin dan tidak memahami peraturan lalu lintas umumnya relatif rendah, kemudian pesepeda berpendapat bahwa usia dan tidak adanya jalur khusus pengguna sepeda/ kendaraan tidak bermotor menjadi salah satu faktor penyebab kecelakaan lalu lintas bagi pesepeda. 


\subsection{Kebiasaan Pengguna Sepeda}

Adapun pengelompokkan ini didapatkan dari hasil pengisian kuesioner pada Bagian III Kebiasaan Pengguna Sepeda yang ditunjukkan oleh Tabel 17.

Tabel 17. Kebiasaan pesepeda di Kota Palu

(*) Bersepeda ke tempat kerja/sekolah/kampus pada saat pandemi Covid-19

\begin{tabular}{lcc}
\hline & Frekuensi & Persen \\
\hline Sangat Jarang & 23 & 17.4 \\
\hline Jarang & 33 & 25.0 \\
\hline Tidak Pernah & 58 & 43.9 \\
\hline Sering & 10 & 7.6 \\
\hline Sangat Sering & 8 & 6.1 \\
\hline Total & 132 & 100 \\
\hline
\end{tabular}

Sebelum Pandemi Covid-19

\begin{tabular}{lcc}
\hline & Frekuensi & Persen \\
\hline Sangat Jarang & 23 & 17.4 \\
\hline Jarang & 33 & 25.0 \\
\hline Tidak Pernah & 58 & 43.9 \\
\hline Sering & 10 & 7.6 \\
\hline Sangat Sering & 8 & 6.1 \\
\hline Total & 132 & 100 \\
\hline
\end{tabular}

(*) Berolahraga atau berkunjung ke tempat wisata pada saat pandemi Covid-19

\begin{tabular}{lcc}
\hline & Frekuensi & Persen \\
\hline Sangat Jarang & 22 & 16.7 \\
\hline Jarang & 48 & 36.4 \\
\hline Tidak Pernah & 31 & 23.5 \\
\hline Sering & 19 & 14.4 \\
\hline Sangat Sering & 12 & 9.1 \\
\hline Total & 132 & 100 \\
\hline
\end{tabular}

Sebelum Pandemi Covid-19

\begin{tabular}{lcc}
\hline & Frekuensi & Persen \\
\hline Sangat Jarang & 22 & 16.7 \\
\hline Jarang & 48 & 36.4 \\
\hline Tidak Pernah & 31 & 23.5 \\
\hline Sering & 19 & 14.4 \\
\hline Sangat Sering & 12 & 9.1 \\
\hline Total & 132 & 100 \\
\hline
\end{tabular}

(*) Bersepeda ke pasar, minimarket, supermarket, dll pada saat pandemi Covid-19

\begin{tabular}{lcc}
\hline & Frekuensi & Persen \\
\hline Sangat Jarang & 24 & 18.2 \\
\hline Jarang & 37 & 28.0 \\
\hline Tidak Pernah & 60 & 45.5 \\
\hline Sering & 5 & 3.8 \\
\hline Sangat Sering & 6 & 4.5 \\
\hline Total & 132 & 100 \\
\hline
\end{tabular}

Lanjutan Tabel 17. Kebiasaan pesepeda di Kota Palu

Sebelum Pandemi Covid-19

\begin{tabular}{lcc}
\hline & Frekuensi & Persen \\
\hline Sangat Jarang & 23 & 17.4 \\
\hline Jarang & 33 & 25.0 \\
\hline Tidak Pernah & 58 & 43.9 \\
\hline Sering & 10 & 7.6 \\
\hline Sangat Sering & 8 & 6.1 \\
\hline Total & 132 & 100 \\
\hline
\end{tabular}

(*) Bersepeda ke rumah teman, tetangga, saudara, dll pada saat pandemi Covid-19

\begin{tabular}{lcc}
\hline & Frekuensi & Persen \\
\hline Sangat Jarang & 28 & 21.2 \\
\hline Jarang & 36 & 27.3 \\
\hline Tidak Pernah & 45 & 34.1 \\
\hline Sering & 16 & 12.1 \\
\hline Sangat Sering & 7 & 5.3 \\
\hline Total & 132 & 100 \\
\hline
\end{tabular}

Sebelum Pandemi Covid-19

\begin{tabular}{lcc}
\hline & Frekuensi & Persen \\
\hline Sangat Jarang & 28 & 21.2 \\
\hline Jarang & 36 & 27.3 \\
\hline Tidak Pernah & 45 & 34.1 \\
\hline Sering & 16 & 12.1 \\
\hline Sangat Sering & 7 & 5.3 \\
\hline Total & 132 & 100 \\
\hline
\end{tabular}

(*) Bersepeda ke tempat makan, cafe, restoran, dll pada saat pandemi Covid-19

\begin{tabular}{lcc}
\hline & Frekuensi & Persen \\
\hline Sangat Jarang & 26 & 19.7 \\
\hline Jarang & 22 & 16.7 \\
\hline Tidak Pernah & 76 & 57.6 \\
\hline Sering & 5 & 3.8 \\
\hline Sangat Sering & 3 & 2.3 \\
\hline Total & 132 & 100 \\
\hline
\end{tabular}

Sebelum Pandemi Covid-19

\begin{tabular}{lcc}
\hline & Frekuensi & Persen \\
\hline Sangat Jarang & 26 & 19.7 \\
\hline Jarang & 22 & 16.7 \\
\hline Tidak Pernah & 76 & 57.6 \\
\hline Sering & 5 & 3.8 \\
\hline Sangat Sering & 3 & 2.3 \\
\hline Total & 132 & 100 \\
\hline
\end{tabular}

Berdasarkan Tabel 17 dapat diketahui bahwa bersepeda untuk berolahraga atau berkunjung ke tempat wisata dan bersepeda ke rumah teman, tetangga atau saudara semakin meningkat pada saat masa pandemi Covid-19, sedangkan bersepeda ke tempat kerja/sekolah/ kantor, bersepeda ke pasar, minimarket/ supermarket serta bersepeda ke tempat makan, cafe, atau restoran semakin menurun pada saat masa pandemi Covid-19. 
REKONSTRUKSI TADULAKO: Civil Engineering Journal on Research and Development, Vol. 3(1), March 2022

\subsection{Persepsi Pesepeda}

Adapun Persepsi Pesepeda oleh para pengguna sepeda di Kota Palu yang diwakilkan oleh responden yang berpartisipasi didapatkan dari hasil pengisian kuesioner pada Bagian IV Persepsi Pesepeda yang ditunjukkan oleh Tabel 18 dan Tabel 19.

Tabel 18. Syarat dan ketentuan bersepeda

(*) Wajib menggunakan helm

\begin{tabular}{lcc}
\hline & Frekuensi & Persen \\
\hline Sangat Tidak Setuju & 2 & 1.5 \\
\hline Tidak Setuju & 1 & 0.8 \\
\hline Netral & 24 & 18.2 \\
\hline Setuju & 41 & 31.1 \\
\hline Sangat Setuju & 64 & 48.5 \\
\hline Total & 132 & 100 \\
\hline
\end{tabular}

(*) Pada malam hari wajib Menggunakan pakaian dengan warna terang dan/atau atribut yang dapat memantulkan cahaya

\begin{tabular}{lcc}
\hline & Frekuensi & Persen \\
\hline Sangat Tidak Setuju & 1 & 0.8 \\
\hline Tidak Setuju & 2 & 1.5 \\
\hline Netral & 21 & 15.9 \\
\hline Setuju & 39 & 29.5 \\
\hline Sangat Setuju & 69 & 52.3 \\
\hline Total & 132 & 100 \\
\hline
\end{tabular}

(*) Berkendara dengan berjajar lebih dari 2 (dua) sepeda

\begin{tabular}{lcc}
\hline & Frekuensi & Persen \\
\hline Sangat Tidak Setuju & 43 & 32.6 \\
\hline Tidak Setuju & 38 & 28.8 \\
\hline Netral & 21 & 15.9 \\
\hline Setuju & 17 & 12.9 \\
\hline Sangat Setuju & 13 & 9.8 \\
\hline Total & 132 & 100 \\
\hline
\end{tabular}

(*) Mengikuti ketentuan perintah dan larangan khusus sepeda yang dinyatakan dengan Alat Pemberi Isyarat Lalu Lintas dan Rambu Lalu Lintas

\begin{tabular}{lcc}
\hline & Frekuensi & Persen \\
\hline Sangat Tidak Setuju & 3 & 2.3 \\
\hline Tidak Setuju & 4 & 3.0 \\
\hline Netral & 16 & 12.1 \\
\hline Setuju & 59 & 44.7 \\
\hline Sangat Setuju & 50 & 37.9 \\
\hline Total & 132 & 100 \\
\hline
\end{tabular}

Berdasarkan Tabel 18 dapat diketahui bahwa pesepeda di Kota Palu setuju bahwa penggunaan helm saat bersepeda dan penggunaan pakaian atau atribut yang dapat memantulkan cahaya saat bersepeda di malam hari wajib dan pesepeda setuju untuk mengikuti ketentuan perintah dan larangan khusus sepeda yang dinyatakan dengan alat pemberi isyarat lalu lintas dan rambu lalu lintas, kemudian pesepeda tidak setuju bersepeda dengan berjajar lebih dari 2 sepeda.
Tabel 19. Persepsi pesepeda

(*) Memudahkan saya menuju ke tempat tujuan meskipun saat itu macet

\begin{tabular}{lcc}
\hline & Frekuensi & Persen \\
\hline Sangat Tidak Setuju & 2 & 1.5 \\
\hline Tidak Setuju & 5 & 3.8 \\
\hline Netral & 37 & 28.0 \\
\hline Setuju & 55 & 41.7 \\
\hline Sangat Setuju & 33 & 25.0 \\
\hline Total & 132 & 100 \\
\hline
\end{tabular}

(*) Menghemat waktu perjalanan

\begin{tabular}{lcc}
\hline & Frekuensi & Persen \\
\hline Sangat Tidak Setuju & 9 & 6.8 \\
\hline Tidak Setuju & 30 & 22.7 \\
\hline Netral & 53 & 40.2 \\
\hline Setuju & 25 & 18.9 \\
\hline Sangat Setuju & 15 & 11.4 \\
\hline Total & 132 & 100 \\
\hline
\end{tabular}

(*) Menyehatkan dan Menyenangkan

\begin{tabular}{lcc}
\hline & Frekuensi & Persen \\
\hline Sangat Tidak Setuju & 3 & 2.3 \\
\hline Tidak Setuju & 4 & 3.0 \\
\hline Netral & 8 & 6.1 \\
\hline Setuju & 54 & 40.9 \\
\hline Sangat Setuju & 63 & 47.7 \\
\hline Total & 132 & 100 \\
\hline
\end{tabular}

(*) Menghilangkan beban/ stress saya

\begin{tabular}{lcc}
\hline & Frekuensi & Persen \\
\hline Sangat Tidak Setuju & 3 & 2.3 \\
\hline Tidak Setuju & 2 & 1.5 \\
\hline Netral & 19 & 14.4 \\
\hline Setuju & 66 & 50.0 \\
\hline Sangat Setuju & 42 & 31.8 \\
\hline Total & 132 & 100 \\
\hline
\end{tabular}

(*) Mengurangi pengeluaran biaya transportasi saya

\begin{tabular}{lcc}
\hline & Frekuensi & Persen \\
\hline Sangat Tidak Setuju & 3 & 2.3 \\
\hline Tidak Setuju & 2 & 1.5 \\
\hline Netral & 32 & 24.2 \\
\hline Setuju & 53 & 40.2 \\
\hline Sangat Setuju & 42 & 31.8 \\
\hline Total & 132 & 100 \\
\hline
\end{tabular}

(*) Meningkatkan kualitas lingkungan (Polusi udara dan kebisingan berkurang)

\begin{tabular}{lcc}
\hline & Frekuensi & Persen \\
\hline Sangat Tidak Setuju & 3 & 2.3 \\
\hline Tidak Setuju & 3 & 2.3 \\
\hline
\end{tabular}


REKOnSTRUKSI TADULAKO: Civil Engineering Journal on Research and Development, Vol. 3(1), March 2022

Lanjutan Tabel 19. Persepsi pesepeda

\begin{tabular}{lcc}
\hline Netral & 7 & 5.3 \\
\hline Setuju & 47 & 35.6 \\
\hline Sangat Setuju & 72 & 54.5 \\
\hline Total & 132 & 100 \\
\hline
\end{tabular}

(*) Mengurangi kemacetan di jalan

\begin{tabular}{lcc}
\hline & Frekuensi & Persen \\
\hline Sangat Tidak Setuju & 4 & 3.0 \\
\hline Tidak Setuju & 3 & 2.3 \\
\hline Netral & 17 & 12.9 \\
\hline Setuju & 50 & 37.9 \\
\hline Sangat Setuju & 58 & 43.9 \\
\hline Total & 132 & 100 \\
\hline
\end{tabular}

(*) Menambah pergaulan/ pertemanan/ sosial

\begin{tabular}{lcc}
\hline & Frekuensi & Persen \\
\hline Sangat Tidak Setuju & 3 & 2.3 \\
\hline Tidak Setuju & 2 & 1.5 \\
\hline Netral & 42 & 31.8 \\
\hline Setuju & 48 & 36.4 \\
\hline Sangat Setuju & 37 & 28.0 \\
\hline Total & 132 & 100 \\
\hline
\end{tabular}

(*) Rawan kecelakaan/ tertabrak kendaraan di jalan raya

\begin{tabular}{lcc}
\hline & Frekuensi & Persen \\
\hline Sangat Tidak Setuju & 7 & 5.3 \\
\hline Tidak Setuju & 20 & 15.2 \\
\hline Netral & 64 & 48.5 \\
\hline Setuju & 26 & 19.7 \\
\hline Sangat Setuju & 15 & 11.4 \\
\hline Total & 132 & 100 \\
\hline
\end{tabular}

(*) Rawan penjambretan atau tindakan kriminal lainnya

\begin{tabular}{lcc}
\hline & Frekuensi & Persen \\
\hline Sangat Tidak Setuju & 8 & 6.1 \\
\hline Tidak Setuju & 15 & 11.4 \\
\hline Netral & 60 & 45.5 \\
\hline Setuju & 35 & 26.5 \\
\hline Sangat Setuju & 14 & 10.6 \\
\hline Total & 132 & 100 \\
\hline
\end{tabular}

(*) Membatasi pergerakan saya ketika harus menuju/ mampir ke beberapa tempat tujuan

\begin{tabular}{lcc}
\hline & Frekuensi & Persen \\
\hline Sangat Tidak Setuju & 9 & 6.8 \\
\hline Tidak Setuju & 24 & 18.2 \\
\hline Netral & 69 & 52.3 \\
\hline Setuju & 23 & 17.4 \\
\hline Sangat Setuju & 7 & 5.3 \\
\hline Total & 132 & 100 \\
\hline
\end{tabular}

Lanjutan Tabel 19. Persepsi pesepeda

(*) Pengendara kendaraan bermotor tidak peduli dengan keselamatan pengguna sepeda

\begin{tabular}{lcc}
\hline & Frekuensi & Persen \\
\hline Sangat Tidak Setuju & 10 & 7.6 \\
\hline Tidak Setuju & 22 & 16.7 \\
\hline Netral & 59 & 44.7 \\
\hline Setuju & 29 & 22.0 \\
\hline Sangat Setuju & 12 & 9.1 \\
\hline Total & 132 & 100 \\
\hline
\end{tabular}

(*) Tidak nyaman karena cuaca tidak mendukung (terlalu panas dan mendadak hujan lebat)

\begin{tabular}{lcc}
\hline & Frekuensi & Persen \\
\hline Sangat Tidak Setuju & 5 & 3.8 \\
\hline Tidak Setuju & 10 & 7.6 \\
\hline Netral & 57 & 43.2 \\
\hline Setuju & 42 & 31.8 \\
\hline Sangat Setuju & 18 & 13.6 \\
\hline Total & 132 & 100 \\
\hline
\end{tabular}

Berdasarkan Tabel 19 dapat diketahui pesepeda setuju bahwa bersepeda dapat memudahkan pesepeda menuju ke tempat tujuan meskipun saat itu macet, menyehatkan dan menyenangkan, menghilangkan beban/ stress, mengurangi pengeluaran biaya transportasi, meningkatkan kualitas lingkungan, mengurangi kemacetan di jalan, menambah pergaulan/ pertemanan/ sosial serta setuju bahwa bersepeda tidak nyaman karena cuaca tidak mendukung.

\section{Kesimpulan}

Berdasarkan rumusan masalah dan hasil pembahasan maka kesimpulan dalam tugas akhir ini adalah:

1). Karakteristik pesepeda di Kota Palu bukan merupakan pesepeda rutin dimana pesepeda umumnya bersepeda dengan tujuan untuk berolahraga atau berkunjung ke tempat wisata, kemudian pesepeda lebih sering bersepeda sendirian dan melakukan perjalanan lebih dari 1 jam dengan jarak total lebih dari 1 kilometer.

2). Perilaku pesepeda di Kota Palu bersepeda secara tertib, menjaga jarak dan memperhatikan keselamatan pengguna jalan lain serta bersepeda dengan penuh konsentrasi dengan memperhatikan situasi lalu lintas $(98,5 \%)$.

3). Keselamatan pesepeda di Kota Palu dapat digambarkan dari tingkat kecelakaan sebesar 43,2\% dimana umumnya terjadinya kecelakaan tunggal $(91,2 \%)$ yang tidak melibatkan pengguna jalan lain. Adapun menurut para pesepeda faktor-faktor yang paling banyak menyebabkan terjadinya kecelakaan lalu lintas saat bersepeda yaitu faktor usia $(80,3 \%)$ dan tidak adanya jalur khusus sepeda/ kendaraan tidak bermotor $(89,4 \%)$.

4). Kebiasaan pesepeda di Kota Palu umumnya meningkat pada saat masa pandemi untuk berolahraga atau berkunjung ke tempat wisata $(10,6 \%)$ dan berkunjung ke rumah teman, tetangga atau saudara $(5,3 \%)$. 
5). Pesepeda di Kota Palu paham kewajiban untuk menggunakan alat pelindung diri dan persyaratan keselamatan saat bersepeda $(79,5 \%)$. Adapun para pesepeda di Kota Palu setuju bahwa bersepeda merupakan kegiatan yang menyehatkan dan menyenangkan $(88,6 \%)$, selain itu juga dapat memudahkan perjalanan $(66,7 \%)$ dan meningkatkan kualitas lingkungan $(90,2 \%)$ walaupun saat bersepeda tidak nyaman karena cuaca yang tidak mendukung $(45,5 \%)$.

\section{Daftar Pustaka}

[1] R. Septika, Y. Hendarso, and S. Soraida, "Gaya Hidup Bersepeda pada Komunitas Bike To Work di Kota Palembang", Media Sosiologi, vol. 22, no. 1, p. 31, 2019.

[2] https://www.gatra.com/detail/news/484403/gayahidup/pengamat-transportasi--pemda-perlu-bangunjalur-sepeda (diakses tanggal 5 April 2021)

[3] K. Wirawan, "Perencanaan Jalur Sepeda Berdasarkan Persepsi dan Preferensi Wisatawan Bersepeda di Pantai Sanur Bali”, Jurnal Invoasi Penelitian, vol. 1, no. 8, p. $1535,2020$.

[4] L. Listantari and J. Soemardjito, "Desain Jalur Sepeda di Wilayah Perkotaan Wonosari Kabupaten Gunungkidul Daerah Istimewa Yogyakarta”, Jurnal Trasportasi Multimoda, vol. 15, no. 1, p.13, 2017.

[5] P. Rusmandani and M.Z. Arifin, "Perencanaan Implementasi Lajur Sepeda di Kota Tegal”, Rekayasa Sipil, vol. 9, no. 1, p0., 2015.

[6] R.R.E. Wahyuni, Nashrullah, and Y.A. Nur, "Integrasi Infrastruktur Sepeda dan Zona Selamat Sekolah", Jurnal Manajemen Bisnis Transportasi dan Logistik, vol. 7 , no. 1, p. 19, 2021.

[7] Devin, G. Pranata, and J. Susanto, "Analisis Efektivitas Lajur Khusus Sepeda pada Kawasan Tomang - Cideng Timur", Jurnal Mitra Teknik Sipil, vol. 4, no. 1., p. 13, 2021.
[8] H.H. Sugasta, S. Widodo, and S. Mayuni, "Analisis Efektivitas Lajur Khusus Sepeda Pada Kawasan Perkotaan Pontianak (Studi Kasus Jalan Sutan Syahrir - Jalan Jendral Urip - Jalan K. H. W. Hasyim - Jalan Merdeka)", Jurnal PWK, Laut, Sipil, Tambang, vol. 4, no. 4, p. 1, 2017.

[9] A. Budiman, "Efektivitas Kebijakan Bersepeda ke Sekolah pada Program Sepeda Gratis untuk Siswa SMP Negeri di Kota Blitar, Provinsi Jawa Timur, Indonesia", Inovasi Pembangunan: Jurnal Kelitbangan, vol. 8, no. 3, p. 205, 2020.

[10] T.A. Laksmana, H. Rachmat, and R. Tahir, "Strategi Pengembangan Wisata Bersepeda Berdasarkan Karakteristik Motivasi Pesepeda Urban (Pada Grup Sepeda TOC dan JGC-SCAM)", Jurnal Pariwisata Terapan, vol. 4, no. 1, p. 73, 2020.

[11] I.T. Mawening, B. Haryadi, and B.H. Setiadji, Strategi Pengembangan Fasilitas untuk Meningkatkan Motivasi Bersepeda Masyarakat Kota Surakarta, Surakarta: Magister Teknik Sipil, 2014.

[12] M.A.S. Pratama, E. Rahmadona, Sudarmadji, and N. Praditya, "Kajian Penerapan Jalur Khusus Sepeda sebagai Transportasi Berwawasan Lingkungan pada Kawasan Kota Palembang dengan Metode BLOS”, Journal of Civil Engineering and Vocational Education, vol. 8, no. 3, p. 190, 2021.

[13] D. Febrianto, Dewanti, and I. Muthohar, "Perilaku Pengendara Sepeda Terhadap Keselamatan di Jalan". Journal of Civil Engineering and Planning, vol. 2, no. 2, p. 150, 2021.

[14] I.P. Windarni, A. Wulandari, and F.R. Hernovianty, "Tingkat Keinginan Masyarakat Menggunakan Jalur Sepeda di Kota Pontianak", Jurnal Elektronik Laut, Sipil, Tambang, vol. 5, no. 3, p. 1, 2018.

[15] I. Indrawan, M.Z. Irawan, and S. Malkhamah, "Faktor Keengganan Pelajar Bersepeda di Yogyakarta", Jurnal Manajemen Aset Infrastruktur \& Fasilitas, vol. 4, no. 1, p. 275, 2020. 
This page is intentionally left blank 